\title{
Estimated seasonal snow cover and snowfall in Japan
}

\author{
TSUTOMU NAKAMURA, \\ Nagaoka Institute of Snow and Ice Studies, NIED, Suyoshi, Nagaoka, Niigata 940, Japan
}

OSAmu ABE

Shinjo Branch of Snow and Ice Studies, NIED, Shinjo, Yamagata 996, Japan

\begin{abstract}
The average amounts of seasonal snow cover and snowfall in Japan were calculated as $7.9 \times 10^{13} \mathrm{~kg}$ and $1.2 \times 10^{14} \mathrm{~kg}$, respectively. The mass of seasonal snow cover of a heavy-snowfall winter, 1980-81 (56-Gosetsu), was calculated as $1.3 \times 10^{14} \mathrm{~kg}$. The amount of $7.9 \times 10^{13} \mathrm{~kg}$ was converted to water equivalent of $230 \mathrm{~mm}$ on the whole snow-covered area, including snow-prone area. A mean of $370 \mathrm{~mm}$ in snow water equivalent was calculated for the snow area where mean snow depth on the ground was more than $10 \mathrm{~cm}$.
\end{abstract}

\section{INTRODUCTION}

The Japanese islands are surrounded by sea and therefore receive quite a lot of precipitation, with an annual average of $1750 \mathrm{~mm}$. In winter the northwesterly monsoon conveys heavy snowfalls, and usually Hokkaido
Island and northwestern Honshu Island are covered by snow. In spring the seasonal snow cover starts to melt; almost all of it has melted away by the beginning of the next winter. Heavy snowfall and the amount of ground snow cover are sometimes troublesome and hazardous, but the snow cover is a water resource. No attempt has

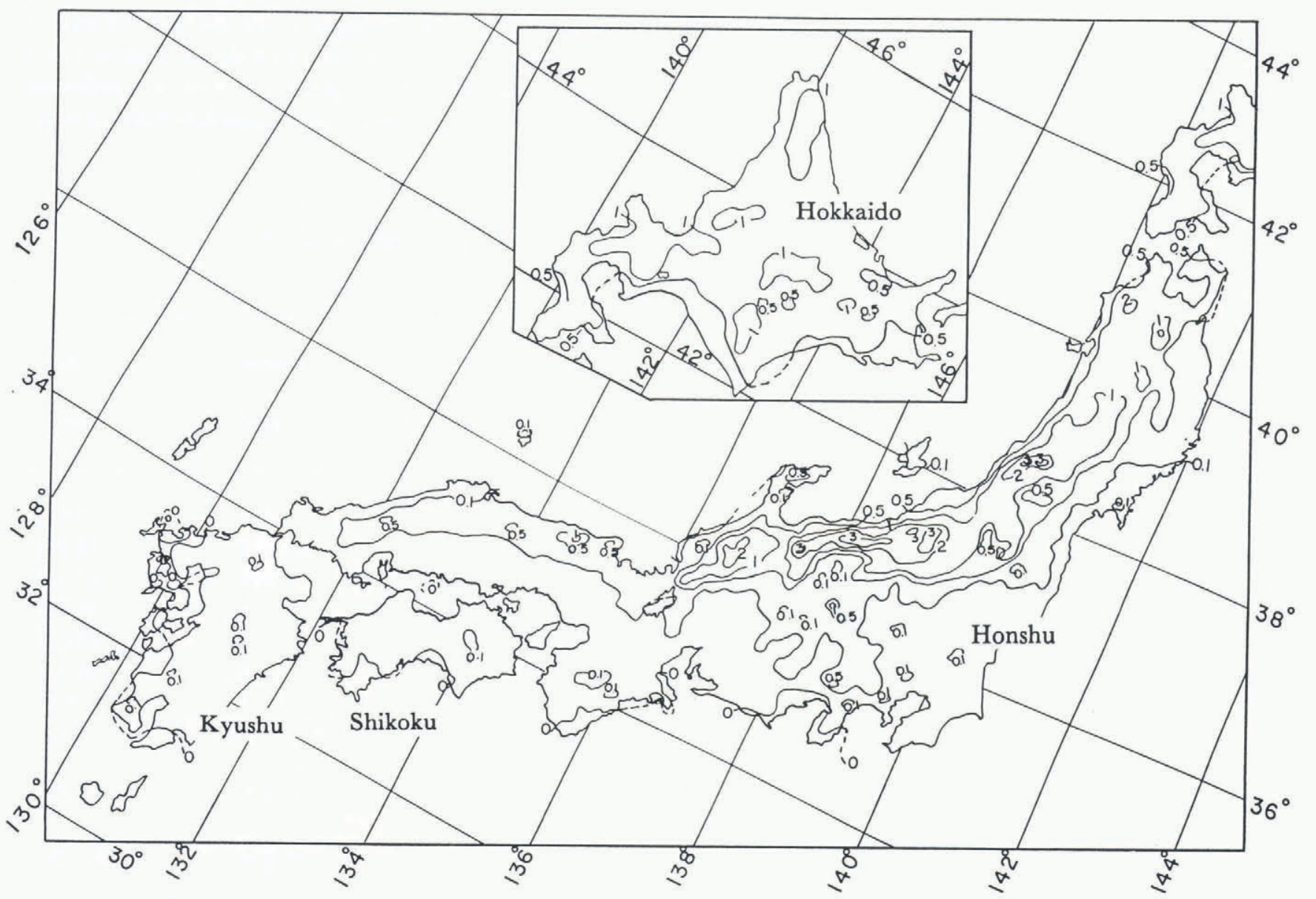

Fig. 1. Distribution of the maximum annual mean depth (m) of snow cover in March from about $1930-45$ (Central Meteorological Observatory, 1949). Redrawn by the authors with simplification. 
been made to calculate the mass of seasonal snow cover in Japan. Furthermore, the amount of snow cover is as good an indicator as ice of global climate change. Average total mass of seasonal snow cover in Japan was estimated by a simple calculation using climatic snow-cover data, i.e. isoline figures of the average of each maximum annual snow-depth zone and data of snow surveys which have been carried out by many workers 1948-54. The total mass of snow cover in a heavy-snowfall season was also calculated by the use of isoline figures of each snow-depth zone. Isoline figures were used for our calculation because maps of isoline figures of each snow-depth zone were more easily available than maps of water equivalent of snow.

\section{PRINCIPLE OF GALGULATION}

The total mass of seasonal snow cover was calculated by the following simple equation.

$$
M=S \times H \times \rho \times 10^{6},
$$

where $M$ is snow mass in $\mathrm{kg}, S$ snow cover area in $\mathrm{km}^{2}, H$ snow depth in $\mathrm{m}$, and $\rho$ snowpack density in $\mathrm{kg} \mathrm{m}^{-3}$.

The total mass of seasonal snowfall was deduced by the total mass of snow cover and a ratio of the masses of the snowfall and snowpack that was obtained at Shinjo, which is located at the boundary region of wet and dry snow in Japan.

\section{METHOD OF GALGULATION}

Average total mass of seasonal snow cover was calculated using climatic data of snowpack area and depth, and average snow density calculated from snow survey data.
Figure 1 shows the distribution of the isolines of the annual mean of the maximum depth of snowpack in March (Central Meteorological Observatory, 1949). The period of observation ranged from 5 to $50 \mathrm{yr}$, depending on the observational station. $42.4 \%$ of the data were from years 10 to $19,28.7 \%$ from years 5 to $9,16.3 \%$ from years 20 to $29,9.2 \%$ from years 30 to 49 and $3.4 \%$ from more than 50 years. The main periods of observation are from about $1930-45$. Table 1 shows the area which corresponds to each region of snow depth in March. Each area circled by an isoline was calculated by a digitizer with a reading accuracy of $0.1 \mathrm{~mm}$ based on the map shown in Figure 1. The middle value of each snow-depth zone in Table 1 was chosen to calculate the snow mass. For example, for the zone of $0.5<H S<1$ the central figure of $0.75 \mathrm{~m}$ was taken as the representative value for the mass calculation.

An average value of snowpack density of $480 \mathrm{~kg} \mathrm{~m}^{-3}$ was used for calculation. This value with a standard deviation of $88 \mathrm{~kg} \mathrm{~m}^{-3}$ was obtained as a mean value of the 84 snow survey areas. Table 2, showing seven examples in 84 areas compiled by Ishihara and Fukui (1955), contains the name of the basins where the snow survey was carried out, the total area of the basin in $\mathrm{km}^{2}$, the mean altitude $(\mathrm{m})$, the total snow sample number obtained in one snow survey, the total mass of snow in the basins (in $10^{6}$ ton), equivalent amount of snowpack of the average and the maximum value $A$ (in $\mathrm{grcm}^{-2}$ ), the maximum snowpack depth $B(\mathrm{~cm})$ in the snow survey and the measured maximum snow density. The measured maximum snow density was the biggest value of the densities which were obtained by each snow survey, i.e. one calculated by the snow mass in each snow sampling and the depth at this sampling. In the last column of Table 2, snow density calculated by the mass shown in $A$ and the maximum snow depth $B$ is shown as a reference value to compare the measured maximum snow density.

Table 1. Area which corresponds to each snow-depth zone with the maximum annual mean in March

\begin{tabular}{crrrrr}
\hline Snow depth & Hokkaido & Honshu & Shikoku & Kyushu & Total \\
\multicolumn{1}{c}{$\mathrm{km}^{2}$} & $\mathrm{~km}^{2}$ & $\mathrm{~km}^{2}$ & $\mathrm{~km}^{2}$ & $\mathrm{~km}^{2}$ \\
\hline & & & & & \\
$0<H S<0.01$ & 0 & 9233 & 4709 & 5453 & 19395 \\
$0.01<H S<0.1$ & 0 & 84089 & 12008 & 27030 & 123127 \\
$0.1<H S<0.2$ & 2349 & 34639 & 285 & 348 & 37621 \\
$0.2<H S<0.5$ & 7184 & 32527 & 0 & 0 & 39711 \\
$0.5<H S<1$ & 5475 & 34162 & 0 & 0 & 88937 \\
$1<H S<2$ & 14625 & 21683 & 0 & 0 & 36308 \\
$2<H S<3$ & 0 & 5632 & 0 & 0 & 5632 \\
$3<H S$ & 0 & 1286 & 0 & 0 & 1286 \\
Total & 78933 & 223251 & 17002 & 32831 & 352017 \\
Total snowless area & 78073 & 227414 & 18256 & 36554 & 360297 \\
\hline
\end{tabular}

* Figures for the total snowless area are from National Astronomical Observatory (1992). 
Table 2. Seven examples among 84 areas where snow surveys were carried out in Japan April 1973-March 1979.

Originally compiled by Ishihara and Fukui (1955)

\begin{tabular}{|c|c|c|c|c|c|c|c|c|}
\hline Number & 1 & 6 & 16 & 22 & 25 & 30 & 34 & Mean \\
\hline River basin & Chubetsu & Yanbetsu & Tadosi & Oirase & Omono & Waga & Minase & - \\
\hline Area $\left(\mathrm{km}^{2}\right)$ & 256.0 & 44.8 & 15.3 & 581.8 & 418.7 & $574^{\circ}$ & 171.69 & - \\
\hline Mean altitude (m) & 1100 & 1008 & - & - & - & - & - & - \\
\hline $\begin{array}{l}\text { Obtained sample } \\
\text { number }\end{array}$ & 172 & 23 & 130 & 58 & 97 & 166 & - & - \\
\hline $\begin{array}{l}\text { Total mass of snow, } \\
\times 10^{6} \text { ton }\end{array}$ & 191.6 & 18.26 & 10.5 & 557 & 304.4 & 230 & 119.0 & - \\
\hline \multicolumn{9}{|c|}{ Amount of snow $\left(\mathrm{g} \mathrm{cm}^{-2}\right)$} \\
\hline average & 75.0 & 41.0 & 68.0 & - & 72.2 & 40.1 & 69.5 & - \\
\hline maximum $(A)$ & 163.0 & 59.0 & 110.0 & - & - & 115.0 & 214.0 & - \\
\hline $\begin{array}{l}\text { Maximum snow } \\
\text { depth }(B)(\mathrm{cm})\end{array}$ & 304 & 215 & 250 & 600 & - & 290 & 332 & - \\
\hline $\begin{array}{l}\text { Measured maximum } \\
\text { snow density }\left(\mathrm{g} \mathrm{cm}^{-3}\right)\end{array}$ & 0.57 & 0.36 & 0.44 & - & - & 0.52 & 0.69 & 0.48 \\
\hline $\begin{array}{l}\text { Calculated snow } \\
\text { density, } A / B\left(\mathrm{~g} \mathrm{~cm}^{-3}\right)\end{array}$ & 0.54 & 0.27 & 0.44 & - & - & 0.40 & 0.64 & 0.40 \\
\hline
\end{tabular}

*Number of snow samples obtained in area per snow survey.

Table 3. Volume $\left(\mathrm{m}^{3}\right)$ and mass $(\mathrm{kg})$ of snow cover in each depth zone in March. Above, volume; below, mass

\begin{tabular}{|c|c|c|c|c|c|c|c|}
\hline$H S$ & MHS & $W E S^{*}$ & Hokkaido & Honshu & Shikoku & Kyushu & Total \\
\hline $\mathrm{m}$ & $\mathrm{m}$ & $\mathrm{mm}$ & & & & & \\
\hline $0<H S<0.01$ & 0.005 & 2.4 & 0 & $4.62 \times 10^{7}$ & $2.36 \times 10^{7}$ & $2.73 \times 10^{7}$ & $9.70 \times 10^{7}$ \\
\hline & & & 0 & $2.22 \times 10^{10}$ & $1.13 \times 10^{10}$ & $1.31 \times 10^{10}$ & $4.66 \times 10^{10}$ \\
\hline $0.01<H S<0.1$ & 0.05 & 24 & 0 & $4.20 \times 10^{9}$ & $6.00 \times 10^{8}$ & $1.35 \times 10^{9}$ & $6.16 \times 10^{9}$ \\
\hline & & & 0 & $2.02 \times 10^{12}$ & $2.88 \times 10^{11}$ & $6.49 \times 10^{11}$ & $2.96 \times 10^{12}$ \\
\hline \multirow[t]{2}{*}{$0.1<H S<0.2$} & 0.15 & 72 & $3.52 \times 10^{8}$ & $5.20 \times 10^{9}$ & $4.28 \times 10^{7}$ & $5.22 \times 10^{7}$ & $5.64 \times 10^{9}$ \\
\hline & & & $1.69 \times 10^{11}$ & $2.49 \times 10^{12}$ & $2.05 \times 10^{10}$ & $2.51 \times 10^{10}$ & $2.71 \times 10^{12}$ \\
\hline \multirow[t]{2}{*}{$0.2<H S<0.5$} & 0.35 & 170 & $2.51 \times 10^{9}$ & $1.14 \times 10^{10}$ & 0 & 0 & $1.39 \times 10^{10}$ \\
\hline & & & $1.21 \times 10^{12}$ & $5.46 \times 10^{12}$ & 0 & 0 & $6.67 \times 10^{12}$ \\
\hline \multirow[t]{2}{*}{$0.5<H S<1$} & 0.75 & 360 & $4.11 \times 10^{10}$ & $2.56 \times 10^{10}$ & 0 & 0 & $6.67 \times 10^{10}$ \\
\hline & & & $1.97 \times 10^{13}$ & $1.23 \times 10^{13}$ & 0 & 0 & $3.20 \times 10^{13}$ \\
\hline \multirow[t]{2}{*}{$1<H S<2$} & 1.5 & 720 & $2.19 \times 10^{10}$ & $3.25 \times 10^{10}$ & 0 & 0 & $5.45 \times 10^{10}$ \\
\hline & & & $1.05 \times 10^{13}$ & $1.56 \times 10^{13}$ & 0 & 0 & $2.61 \times 10^{13}$ \\
\hline \multirow[t]{2}{*}{$2<H S<3$} & 2.5 & 1200 & 0 & $1.41 \times 10^{10}$ & 0 & 0 & $1.41 \times 10^{10}$ \\
\hline & & & 0 & $6.76 \times 10^{12}$ & 0 & 0 & $6.76 \times 10^{12}$ \\
\hline \multirow[t]{2}{*}{$3<H S$} & 3.5 & 1700 & 0 & $4.50 \times 10^{9}$ & 0 & 0 & $4.50 \times 10^{9}$ \\
\hline & & & 0 & $2.16 \times 10^{12}$ & 0 & 0 & $2.16 \times 10^{12}$ \\
\hline \multirow[t]{3}{*}{ Total } & & & $6.59 \times 10^{10}$ & $9.76 \times 10^{10}$ & $6.67 \times 10^{8}$ & $1.43 \times 10^{9}$ & $1.66 \times 10^{11}$ \\
\hline & & & $3.16 \times 10^{13}$ & $4.68 \times 10^{13}$ & $3.20 \times 10^{11}$ & $6.87 \times 10^{11}$ & $7.94 \times 10^{13}$ \\
\hline & & & $400^{* *}$ & $210^{* *}$ & $19^{* *}$ & $21^{* *}$ & $\begin{array}{l}230^{* *} \\
370^{* * *}\end{array}$ \\
\hline
\end{tabular}

*Water equivalent of snow (WES) in mm.

**WES (in $\mathrm{mm}$ ) of area-weighted mean value.

${ }^{* * *}$ WES (in $\mathrm{mm}$ ) of area-weighted mean value for the area with snow depth more than $0.1 \mathrm{~m}$. 


\section{RESULTS AND DISGUSSION}

Table 3 shows the calculated results of the volume and mass of snow cover in March at each snow-depth zone in four islands. An average of the total amount of seasonal snowpack in March calculated from Equation (1) was $7.9 \times 10^{13} \mathrm{~kg}$. Because the maximum water equivalent of snow is usually observed at the end of February or early March, this amount is considered to be close to the average of the maximum amount of seasonal snow cover in Japan. For instance, in winter 1979-80, in both Nagaoka and Shinjo, the maximum was observed at the end of February and in Sapporo at the end of March. Nagaoka and Shinjo are located on Honshu Island, at latitudes $37.3^{\circ} \mathrm{N}$ and $38.5^{\circ} \mathrm{N}$ and at elevations of $97 \mathrm{~m}$ and $127 \mathrm{~m}$ a.s.l., respectively. On the other hand, Sapporo is located on Hokkaido Island, at latitude $43^{\circ} \mathrm{N}$ and at elevation of about $17 \mathrm{~m}$ a.s.l. These three locations are considered to be the representative points in the snowy area of Japan, therefore it is assumed that the maximum water equivalent of snow is found at the end of March in Japan. In Table 3 both the water equivalent of snow (WES) and the WES of area-weighted mean value are shown.

Figure 2 shows variations of snow density on $25 \mathrm{March}$ at different water equivalents of snow and snow depths for four points: Sapporo, Shinjo, Nagaoka and Tokamachi. The measured densities range between 400 and $500 \mathrm{~kg}$ $\mathrm{m}^{-3}$. Though these points are located on the plains, these measured densities support the usage of the density $480 \mathrm{~kg} \mathrm{~m}^{-3}$ for calculation of the total amount of snow in Japan.

In the course of the analysis the authors realized that there is a rather large difference between the maximum water equivalent of snow cover on the ground and the total amount of snowfall in a winter. On the other hand, it is well known that the maximum mass of snow cover on the ground, i.e. the maximum amount of water

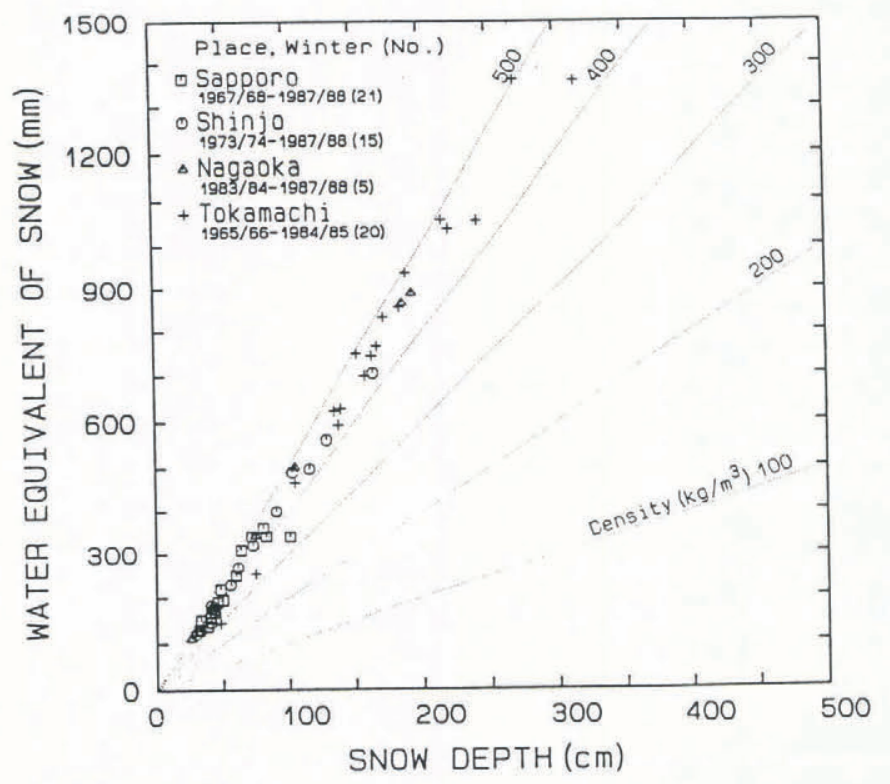

Fig. 2. Snowpack density distribution on 25 March as functions of water equivalent of snow and snow depth at four locations.
Table 4. Comparison of the three kinds of snow amount (mean of 14 winters from 1974-75 to 1987-88, Shinjo)

Methods Snow amount Ratio $\mathrm{mm} \mathrm{a}^{-1}$
Precipitation:

Measured by rain gauge*

Calculated by summation of newly fallen snow depth and density

Snowpack: Maximum water equivalent, $\mathrm{HW}$
559.8 $\frac{559.8}{588.3}=0.952$

588.3

$$
\frac{588.3}{588.3}=1
$$

$$
\frac{398.1}{588.3}=0.677
$$

\footnotetext{
* Values from the beginning of winter until maximum
} HW observed in each winter.

equivalent of snow, appears some days after the date of the maximum snow depth. Sakurai and others (1992) calculated the differences between these dates for 12 locations, including Sapporo, Shinjo and Tokamachi. Differences varied from 11 to 23 days over periods of observation ranging from 11 to 46 years according to location. In Sapporo the difference was 18.6, in Shinjo 15.2 and in Tokamachi 20.1 days. Table 4 compares three kinds of snow amount: precipitation measured by rain gauge; precipitation calculated by the depth of newly fallen snow measured together with density each morning; and maximum water equivalent of snow cover measured on the ground each winter. The data in Table 4 are the means of the 14 winters from $1974-75$ to $1987-88$ measured at Shinjo. The amount obtained from density and depth is the largest of the three, and is considered to show the natural precipitation adequately as this mode of calculation is the best at present. Therefore, the amount of precipitation was used as a base to compare the amount of snow cover on the ground. The ratio of 0.677 was obtained by a comparison between the snowfall amount calculated by density and by depth. The total amount of the newly fallen snow was measured until the date when the maximum water equivalent of snow on the ground was observed. The same ratio of 0.677 was applied to calculate the total amount of seasonal snowfall in Japan until the time when the maximum water equivalent of snow is observed. Then, an amount of $1.2 \times 10^{14} \mathrm{~kg}$ was obtained as the total mass of seasonal snowfall at the time when the maximum water equivalent of snow cover is observed on the ground.

Some winters have a lot of heavy snowfall. Table 5 shows one example of the snow area with each snowdepth zone in a heavy snowfall winter (winter of 1980-81, which in Japanese is called $56-$ Gosetu) calculated from 
Table 5. Snow-cover area in each snow-depth zone at $0900 \mathrm{~h} 28$ February 1981 (56-Gosetsu) in Japan

\begin{tabular}{|c|c|c|c|c|c|}
\hline$H S$ & Hokkaido & Honshu & Shikoku & Kyushu & Total \\
\hline $\mathrm{m}$ & $\mathrm{km}^{2}$ & $\mathrm{~km}^{2}$ & $\mathrm{~km}^{2}$ & $\mathrm{~km}^{2}$ & \\
\hline $0.5<H S<1$ & $3.05 \times 10^{4}$ & $2.98 \times 10^{4}$ & $3.16 \times 10^{3}$ & 0 & $6.35 \times 10^{4}$ \\
\hline $1<H S<2$ & $3.32 \times 10^{4}$ & $3.66 \times 10^{4}$ & 0 & 0 & $6.99 \times 10^{4}$ \\
\hline $2<H S<3$ & $2.44 \times 10^{3}$ & $2.19 \times 10^{4}$ & 0 & 0 & $2.43 \times 10^{4}$ \\
\hline $3<H S<4$ & 0 & $1.11 \times 10^{4}$ & 0 & 0 & $1.11 \times 10^{4}$ \\
\hline $4<H S<5$ & 0 & $3.07 \times 10^{3}$ & 0 & 0 & $3.07 \times 10^{3}$ \\
\hline $5<H S$ & 0 & $2.84 \times 10^{2}$ & 0 & 0 & $2.84 \times 10^{2}$ \\
\hline Total & $6.61 \times 10^{4}$ & $1.03 \times 10^{5}$ & $3.16 \times 10^{3}$ & 0 & $1.72 \times 10^{5}$ \\
\hline
\end{tabular}

Table 6. Volume $\left(\mathrm{m}^{3}\right)$ and mass $(\mathrm{kg})$ of snow cover in each depth zone at $0900 \mathrm{~h} 28$ February 1981 in Japan. Above, volume; below, mass. Snow density of $480 \mathrm{~kg} \mathrm{~m}^{-3}$ was used to calculate mass from volume

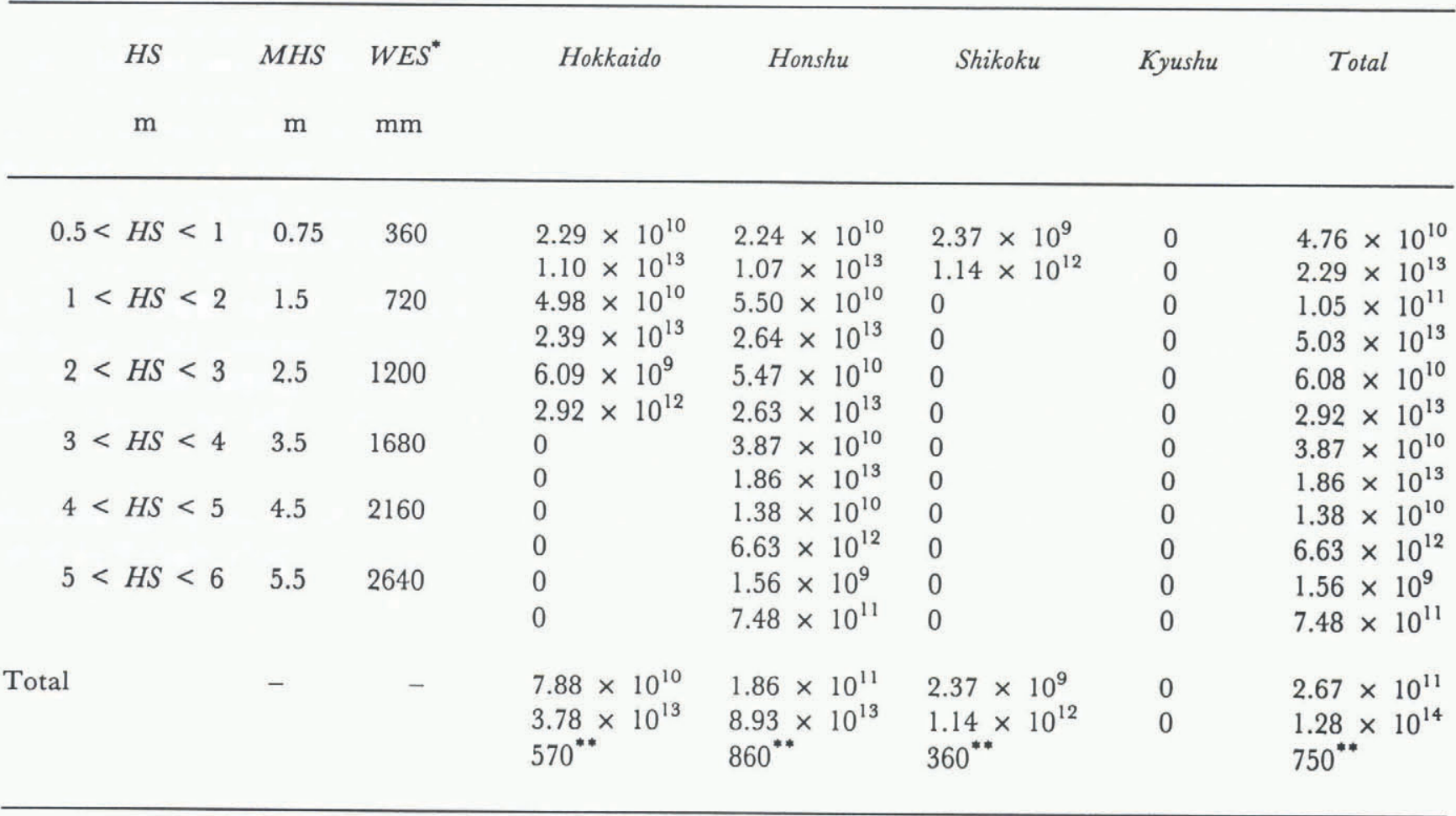

*Water equivalent of snow (WES) in mm.

"* WES (in $\mathrm{mm}$ ) of area-weighted mean value.

the isolines of heavy snowfall (Japan Meteorological Agency, 1981). Table 6 shows the calculated snow volume and mass at each island with each snow-depth zone. The total mass of snow cover more than $0.5 \mathrm{~m}$ deep observed on the ground was calculated as $1.3 \times 10^{14} \mathrm{~kg}$. This amount is much larger than the average mass of $7.9 \times 10^{13} \mathrm{~kg}$ obtained above: an increase by $5.1 \times 10^{13} \mathrm{~kg}$ corresponding to $64 \%$ is observed.

An area-weighted mean value of $230 \mathrm{~mm}$ in water equivalent of snow was calculated for the whole snow- covered area shown in Figure 1. But these figures do not seem to show the real situation of the mean amount of snow in the so-called snow areas of Japan, because the climatic isolines shown in Figure 1 include both the spatial and temporal average. In about half of Honshu Island, and in almost all of Kyushu and Shikoku islands, we do not have snow cover in most years. Occasionally these areas are covered by snow, therefore they are recognized as areas with snow cover of less than $10 \mathrm{~cm}$ on average, i.e. these areas are perceived as snow-prone 
areas. By this reason it will be acceptable for us to use the amount of $370 \mathrm{~mm}$ as the mean of the water equivalent of snow in the so-called snowy areas of Japan with snow more than $10 \mathrm{~cm}$ deep on the ground, and covering an area of $209495 \mathrm{~km}^{2}$. The amount of $370 \mathrm{~mm}$ was calculated using both the total mean mass of $7.64 \times$ $10^{13} \mathrm{~kg}$ and the weighted area.

The accuracy of area measurements ranged from $0.3 \%$ for the snow-area zones $0.5-2 \mathrm{~m}$ deep which cover most of the snow mass, to $7 \%$ for the smallest area of the deepest snow zone. Mean snow densities observed at 48 snow survey areas ranged from 330 to $650 \mathrm{~kg} \mathrm{~m}^{-3}$. Their average of $480 \mathrm{~kg} \mathrm{~m}^{-3}$ was used for the calculation, with a standard deviation of $88 \mathrm{~kg} \mathrm{~m}^{-3}$. If we assumed the distribution of each calculated mass (which was calculated by the use of each mean snow density obtained in the 48 areas, which data were anlyzed to obtain the average snow density $480 \mathrm{~kg} \mathrm{~m}^{-3}$ ) shows a normal distribution, the standard deviation means that the mass of snow cover ranging from $6.5 \times 10^{13}$ to $9.4 \times 10^{13} \mathrm{~kg}$ corresponds to $68.3 \%$ of the mass distribution.

\section{CONGLUSIONS}

In this paper average masses of seasonal snow cover and snowfall in Japan were calculated respectively as $7.9 \times 10^{13}$ and $1.2 \times 10^{14} \mathrm{~kg}$. A maximum amount of snowfall of $1.3 \times 10^{14} \mathrm{~kg}$ was calculated for the winter of 1980-81 (56-Gosetsu). The seasonal snow cover of $7.9 \times$ $10^{13} \mathrm{~kg}$ corresponds to a mean precipitation of $230 \mathrm{~mm}$ on the whole snow-covered area of the Japanese islands. A mean precipitation of $370 \mathrm{~mm}$ will be a real mean on the so-called snow-covered area of $209495 \mathrm{~km}^{2}$ in Japan, where the mean snow depth is more than $10 \mathrm{~cm}$ on the ground. It is understood that there is a difference between the water equivalent of the snow cover on the ground and snowfall. Especially, in comparison with Hokkaido Island, on Honshu Island this difference will be larger because of the melting due to higher air temperatures in spring.
The amount of snow, i.e. the extent of the snowcovered area and the mass of snow cover, will be an index of the coldness for each winter, and variation in snow amount will be an index of climate change. Furthermore, the snow mass itself and the mass change in time and space must be important in consideration of isostasy and the rotation of the Earth. For these purposes it will be necessary to determine snow amount and distribution in space and in time in more detail, as soon as possible. For this purpose the development of remote-sensing techniques in snow and ice areas is strongly desired.

\section{ACKNOWLEDGEMENT}

The authors express their hearty thanks to the referees and editors for their help with the manuscript. They also wish to express their thanks to Miss Yuko Iwaki for typing this manuscript.

\section{REFERENCES}

Central Meteorological Observatory. 1949. The climatography of snow in Japan. Niigata, Snow Association of Japan.

Ishihara, K. and A. Fukui. 1955. Examples of snow survey in Japan. In Researches on Snow and Ice No. 2. Tokyo, Japanese Society of Snow and Ice, 203-236.

Japan Meteorological Agency. 1981. A heavy snowfall in the Hokuriku-Tôhoku area from the middle of December 1980 to the end of February 1981. Tokyo, Japan Meteorological Agency. Forecast Department. (Report of the Natural Phenomena Accompanying Disasters 1.)

National Astronomical Observatory. 1992. Chronological scientific tables (Rika nenpyo). Tokyo, Maruzen Co. Ltd.

Sakurai, S., O. Joh and T. Shibata. 1992. Statistical analysis of annual extreme ground snow loads for structural design. Journal of Structural and Construction Engineering 437, 1-10.

The accuracy of references in the text and in this list is the responsibility of the authors, to whom queries should be addressed. 